\title{
Local Preferences for Shea Nut and Butter Production in Northern Benin: Preliminary Results
}

\author{
Dolores Agúndez ${ }^{1,2, *} \mathbb{C}$, Théodore Nouhoheflin ${ }^{3}$, Ousmane Coulibaly ${ }^{3}$, Mario Soliño ${ }^{4}$ and \\ Ricardo Alía 1,2 \\ INIA-CIFOR, Carretera de la Coruña km 7.5, 28040 Madrid, Spain; alia@inia.es \\ 2 iuFOR, Sustainable Forest Management Research Institute, University of Valladolid \& INIA, \\ Avd. Madrid s/n, 34004 Palencia, Spain \\ 3 LARCASS, Laboratory of Analysis and Capacity Strengthening in Social Sciences, 09 BP 932 Cotonou, Benin; \\ tnouho@gmail.com (T.N.); o.coulibaly1995@gmail.com (O.C.) \\ 4 Department of Economic Analysis \& ICEI, Complutense University of Madrid, 28223 Pozuelo de Alarcón, \\ Spain; msolino@ucm.es \\ * Correspondence: agundez@inia.es
}

Received: 30 October 2019; Accepted: 14 December 2019; Published: 19 December 2019

\begin{abstract}
Shea products in Benin (West Africa) are produced in a low-developed agroindustry, but they are estimated to be the country's third largest export. The nut harvesting and quality guaranteeing in the butter process can only be achieved through improvements in the value chain, thus making it more attractive for stakeholders. The aim of this paper is to provide keys to a better product valorization, obtain a significant increase in household incomes based on shea butter marketing opportunities, and offer competitive products at the local and regional markets. Different markets were designed to catch processors and consumers' preferences for two improved shea products: butter and nuts in Northern Benin. An open-ended contingent valuation (CV) was applied, and the willingness to pay (WTP) and willingness to accept (WTA) were estimated by using a typical ordinary least squares (OLS) modelling approach. On local markets in Benin, the color, length, and weight of the nuts, as well as the color, smell, and texture of shea butter significantly influence, respectively, the processors' willingness to accept and the consumers' willingness to pay for a specific quality level. An increase in price would ensure the quality of the shea butter and would be covered by the premium to be paid by consumers. Certification design and the development of shea resources management and conservation programs should include ethnic preferences and consider gender, to avoid reducing women's profits in the shea butter local market.
\end{abstract}

Keywords: Vitellaria paradoxa; Butyrospermum parkii; agroforestry; market; non-wood forest product; contingent valuation; food; gender; Fulani

\section{Introduction}

Shea (Vitellaria paradoxa C.F. Gaertn, Sapotaceae) is one of the most important natural tree species of the Sudan-Guinean mixed open forest, in the green belt from Senegal to Ethiopia. It is present mainly in the agroforestry parks and fallows, in which various crops are grown among the trees (cotton, millet, maize, groundnut, cowpea, etc.) and in the remaining protected forests. The shea tree has traditionally been preserved alongside cultivation because of the high socioeconomic value given to shea butter, the main product resulting from the processing of its nuts that has multiple food, cosmetic, therapeutic, cultural, and religious uses. This nontimber forest product contains $45-55 \%$ of a solid cooking oil above $33^{\circ} \mathrm{C}$, and it means employment for over 18 million women collectors in Sub-Saharan Africa [1].

Nowadays, shea trees are the second most important oil crop in Africa, after the palm nut tree [2]. The trade of shea kernels in the international market, mainly for the use of their butter in cosmetics 
and as a fat in the production of chocolate, has been increasing since the 2000s. Western Africa represents $99.8 \%$ of total exports of shea nuts, whereas smaller quantities come from the eastern regions. Production and export estimates are that West Africa currently exports between 265,000 and 445,000 tons of shea nuts per year. The main exporters are Ghana, Burkina Faso, Benin, Côte d'Ivoire, Nigeria, Mali, and Togo [3]. Despite the potential and value of the shea tree products, there is a general regressive trend that raises high concerns about the conservation of the species and the supply of shea nuts [1,4-7].

Approximately half of the production of shea nuts has traditionally remained in the producing countries, and between 57\% [3] and 41\% [8] of the shea butter is consumed by domestic households. Production mainly meets the local demand, especially through the local markets, but it is not counted in the official statistics [7]. Many authors estimated that the international market potential of shea products would eventually lead to an improvement in the economies of the producing countries, their farmers, and especially the women involved [1,2,9-16]. However, the globalization of the market of this product had a weak impact on the reorganization at the regional scale. Even an increase in prices in, for example, Burkina Faso, hardly affected the quality standards and organization of the value chain governance at the local level $[17,18]$.

The traditional production of shea butter is considered a woman's task, from the collection of the fruits in the area surrounding the villages to the sale and/or consumption of the butter at the household level, which makes women the main stakeholders in its value chain $[10,19]$. It is estimated that shea butter production is a source of income for hundreds of thousands of rural women [18], and that it is mainly considered as part of the household's subsistence income [20]. The majority of the processing of the kernels for their transformation into butter is still done by using traditional techniques, which are inefficient and lowers the quantity and quality of shea butter available in the market. The technical solutions required to improve the process are not, however, generally accessible to these women [21], in spite of the great importance of the shea products to their domestic economies.

The results of previous research point out the urgent need to improve the yield [10] and quality of shea butter production for the market [13]. In Benin, shea products are considered to be the country's third largest export, after cotton and cashews [22], but the sector has experienced a relatively limited development and represents only $2 \%$ of the world production [23]. The quality of the locally produced nuts speaks to Benin's untapped potential as a production country, but efforts to build a national market for shea butter remain to be made, as well as efforts to give added value to shea products, through the increased higher quality [24]. Meanwhile, the kernels are still sold at the local market or exported, and the butter produced is still consumed in the household or sold in the local or regional markets [25]. A production technique that effectively preserves the quality of the nuts and the butter would have a significant positive effect in the value chain, increase competitiveness, and, therefore, the local income [6].

Market accessibility remains a major challenge because shea processors are price takers and cannot provide the required quality consistency [3]. To solve this problem, some financial organizations have established technical support services, providing processing facilities for the producers [9]. Different initiatives, such as the Global Shea Alliance and the Association Karité Bénin, among others, aim at developing appropriate criteria for quality standards, provenance definitions, and processing procedures, as well as tree management and agricultural practices for nut production.

This study aims to offer preliminary key elements to more competitive shea products at the local and regional markets, as increased marketing opportunities would lead to higher domestic income. To do so, this study primarily focused on local preferences across the shea value chain in Northern Benin. An open-ended contingent valuation (CV) was applied, and the willingness to pay (WTP) and willingness to accept (WTA) were estimated by using a typical ordinary least squares (OLS) modelling approach. The main characteristics affecting the quality of the nuts and of the butter are described, as well as the socioeconomic factors influencing several steps in the value chain.

More specifically, the objective is to analyze the preferences of the local actors in regard to a future market in which a better quality of butter can be produced by (i) assessing processors' and 
consumers' preferences of the nut and butter quality available on the markets; (ii) analyzing the likely factors affecting better quality, and (iii) determining the marginal price to be paid/accepted when improving quality.

\section{Materials and Methods}

\subsection{Area of Study}

The area of study was selected due to the high socioeconomic value generated by the shea tree in the Bembereké parkland and more precisely in the Kalalé municipality (Figure 1), where 27\% of the rural population is involved in the production and processing of shea products [26,27]. The main activity in the area is agriculture, the most important source of income for $80 \%$ of the population. Major crops grown are cotton, yams, maize, sorghums, cassavas, and groundnuts.

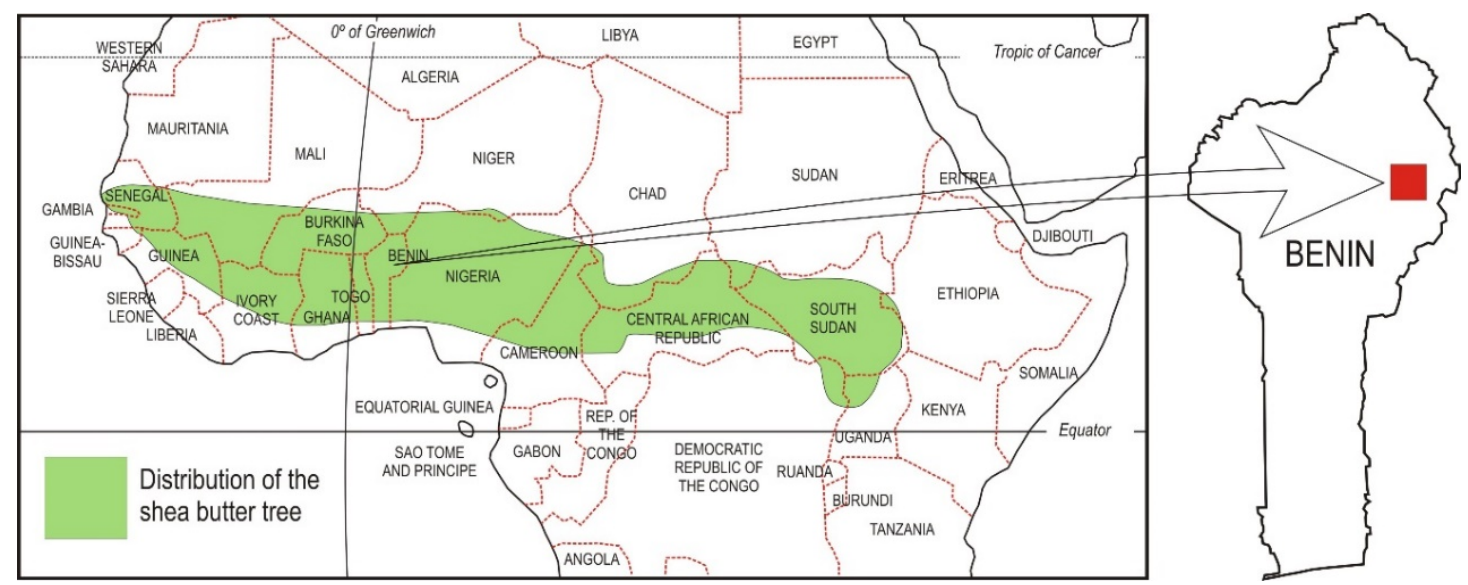

Figure 1. Greenbelt distribution of the shea tree and location of the study area in North Benin (in red).

\subsection{The Sample}

Three districts belonging to the Kalalé municipality were selected on the basis of their high role in shea butter production, their accessibility, and the existence of a local market. The main groups of stakeholders at the local shea value chain were selected for the interview, considering that women are the main task force. Women process nuts into butter, either through buying or self-collecting nuts, and then sell the butter. The processors' group was composed only of women, while the consumers' group was composed by both women and men. Women consumers interviewed at the local market are not involved in the production of butter and mostly buy it; men consumers interviewed at the household level are farmers with property rights on the land and/or on the shea trees. A sample of 319 individuals were contacted, and 307 were valid responses, i.e., completed surveys (Table 1).

Table 1. Survey districts in the municipality of Kalalé and total number of respondents.

\begin{tabular}{ccccc}
\hline Districts & $\begin{array}{c}\text { Nut-into-Butter } \\
\text { Processors (Women) }\end{array}$ & $\begin{array}{c}\text { Consumers } \\
\text { (Men at Household) }\end{array}$ & $\begin{array}{c}\text { Consumers } \\
\text { (Women at Market) }\end{array}$ & Total \\
\hline Dérassi & 49 & 25 & 47 & \\
Péonga & 23 & 15 & 23 & \\
Kalalé center & 51 & 32 & 112 & 184 \\
\hline Total & 123 & 72 & 112 & 123 \\
\hline WTP butter & & 72 & & 123 \\
\hline WTA butter & 123 & & & 184 \\
\hline WTP nuts & 123 & & & \\
\hline
\end{tabular}




\subsection{The Survey Design}

The contingent valuation (CV) is a survey-based method. Two different questionnaires (for processors and consumers) were developed, including three different sections each. The survey was conducted with the support of independent interviewers for all the local languages (Boo, Fulani, and Baatonou) of those who filled up the questionnaires. Each interview was performed for a maximum time of 30 minutes. Women processors and men consumers were met at their homes, to answer the questionnaire, while women consumers were met at the local market, just after buying shea butter.

The first section of the questionnaire was common for shea processors and butter consumers, including 10 general questions about the respondent: ethnic group, age, level of education, household descriptions, and main activities of the respondent and his or her family.

The interviewed people belonged to different ethnic groups, including the Boo (57.5\%), Fulani (15.9\%), Gando (a different ethnic group that also speaks Fulani, 14.3\%), and Baatombu (12.3\%). The average age of respondents was 46 years old for men (min: 25; max: 80) and 40 years old for women (min: 17; max: 70 ). Fifty percent of the men received no formal education, $29 \%$ primary school, $17 \%$ secondary school, and $4 \%$ higher education. Ninety four percent of the women received no formal education and just $6 \%$ primary school. The household size was on average 10 people, with six persons active, involved in farm activities. The main activity was agriculture, which was also the main source of income.

Rural activities occupied two-thirds of the women, followed by processing $(19 \%)$ and petty trading $(16 \%)$. Women became more involved in field activities during the farming season, being, in general, more active in processing and trading activities.

The second section of the questionnaire included up to 8 questions about the factors affecting shea nut and butter production and quality: the source, period of acquisition, characteristics defining and factors affecting the quality and variation in the price for nuts and/or butter. Consumers were asked about the different usages of different, better grades of butter, the period over which the butter was mostly commercialized, and the origin and types of the butter. Processors were also asked about processing frequency and marketing of the butter. The major constraints associated with the processing of nuts into butter were also collected. This section allowed the identification of the factors affecting shea nut and butter production and quality

The third section of the questionnaire constituted the main exercise of the study and contained $5 \mathrm{CV}$-related questions. Processors were asked about the premium they were willing to pay (WTP) for a change of better-quality nuts and the price they were willing to accept (WTA) for better-quality butter. Consumers were asked about WTP for a better quality of butter (i.e., a shea butter with improved organoleptic characteristics). An open-ended format was used for the CV exercise, and the respondents were asked the following question: "How much are you willing to pay or to accept for a change dealing with a better quality of the product (nuts or butter)?" The currency used is the West African CFA Franc $(\mathrm{XOF})$, which has an exchange rate that is pegged to the euro (EUR $=$ XOF 655.957). Data were collected between November 2004 and February 2005 (see Supplementary Materials). The reference market price was XOF 1000 for approximatively $25 \mathrm{~kg}$ of nuts, and $100 \mathrm{XOF}$ for approximatively $125 \mathrm{~g}$ of butter. Thus, WTP/WTA referred to these weights.

\subsection{Contingent Valuation Method}

The contingent valuation (CV) method [28] is based on the design of a hypothetical market in which a new product is commercialized. In the CV application, individuals were asked about their maximum willingness to pay (WTP) or minimum willingness to accept (WTA) for an improved and currently nonmarketed shea product. There are several ways to ask people about the WTP/WTA: open-ended questions, dichotomous format question, payment card, ranking, choice, etc. The choice of the elicitation format still represents an interesting academic debate [29]. In this paper, the open-ended format was used. Therefore, we directly asked people about their maximum WTP and minimum WTA, and avoided giving implicit clues to stakeholders about the value of shea products. We recognize that one of the main drawbacks of this elicitation format is that it can lead to overstating or understating 
WTP values [30], being quite different attending to the public or private character of the goods (public vs. market). Different markets were designed to assess the preferences of the stakeholders for shea butter and nuts. The method was used to analyze the processors and consumers' preferences and decisions on improved characteristics of shea nuts and butter. Moreover, a descriptive analysis dealing with the variables influencing the WTP/WTA was performed thorough an ordinary least squares modelling (OLS). Previously, Pearson correlation analyses were used to select the key variables that could explain the WTP/WTA of the new hypothetical products. The OLS model is specified as follows:

$$
Y_{i}=\beta_{0}+\beta_{i} X_{i}+\varepsilon_{i}
$$

where the dependent variables $(Y)$ were the individual WTP or WTA; $X$ is the vector of variables influencing the monetary amount that an individual is willing to pay/accept for the new shea-based products, i.e., nuts and butter of better quality than the ones currently sold at the local markets; $\beta$ is a vector of parameters to be estimated; and $\varepsilon$ is a random error term normally distributed with a zero mean and constant variance. The WTP and WTA were calculated as the average sample mean of the open responses $\left(\Sigma_{i=1} \ldots n Y_{i} / n\right)$, where $n$ is the sample size.

\section{Results}

\subsection{Identification of the Factors Affecting Shea Nut and Butter Production and Quality}

The main factors identified by respondents affecting the shea nuts and butter production and quality are shown in Table 2 . The collection of the nuts takes place mainly during the rainy season. Nuts are picked and/or purchased without a clear grading technique. However, all the women processors recognized which nuts are better quality than others and mentioned maturity as the first criterion when selecting nuts for processing. Maturity was assessed based on physical features, such as the color, weight, diameter, and length of the nuts. A mature nut was recognized by its brownish color and by its weight: the heavier the nut, the better its quality and that of the butter.

Table 2. Identification of factors affecting nut and butter production and quality.

\begin{tabular}{ccc}
\hline Shea Butter Challenges & & \% of Processors \\
\hline Traditional processing & Low production & 55.3 \\
& Low extraction rate & 44.7 \\
\hline Marketing constraints & Low production & 77.2 \\
& Flow & 21.1 \\
& Butter conservation & 19.5 \\
& Lack of marketing opportunities & 5.7 \\
\hline Diameter & Large & \% of Processors \\
& Short & 13 \\
\hline Length & Large & 87 \\
& Short & 40 \\
\hline Weight & Heavy & 60 \\
Color & Brown & 100 \\
& Shea Butter Characteristics & 100 \\
\hline Color & White-gray & of Consumers \\
& Yellow & 66 \\
\hline Odor & Slightly floral & 28 \\
Flavor & Slightly fruity & 96 \\
\hline Texture & Solid & 100 \\
\hline
\end{tabular}


The processing techniques were described as traditional, i.e., manual, even if some form of semi-mechanization, in the form of a mill as crusher/grinder of the nuts (Figure 2), was observed at a few processing units. The remainder of the processing steps were much easier and did not require special equipment, although they were time intensive.

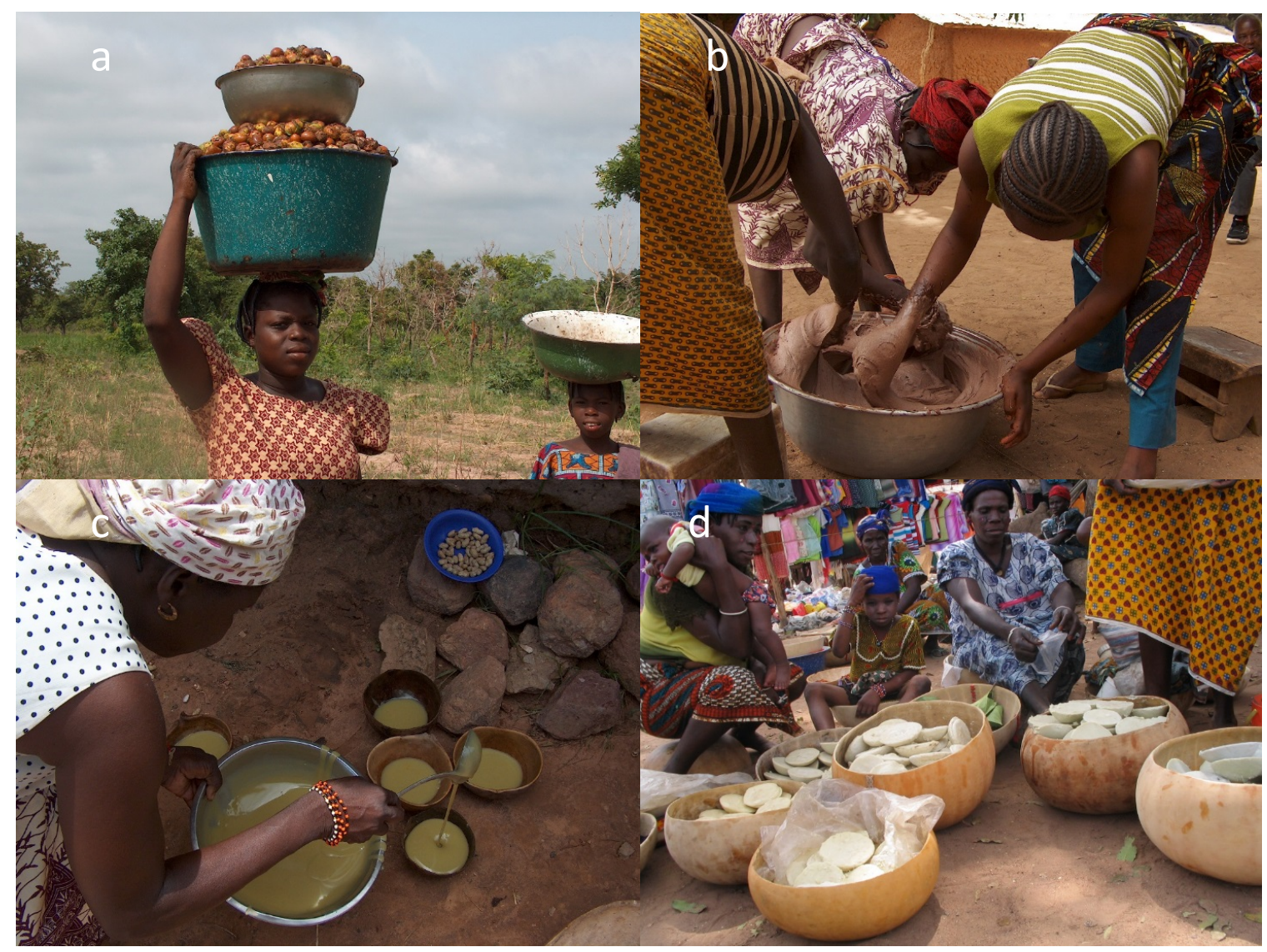

Figure 2. Pictures taken during the study in Kalale show some of the steps in traditional process: young girls collecting shea nuts (a), women churning the shea paste (b), hot shea butter being poured into calabash molds (c), and selling butter at the local market (d).

Shea nut processors were aware about the challenges associated with the traditional process, (Table 2) such as its low production capacity and the low rate of butter extraction. The constraints women processors found related to the marketing of shea butter were said to be low production capacity, difficulties in flow, butter conservation, and lack of market opportunities.

Results showed that several categories of butter were produced. Women processors attribute these differences to the quality of the nuts used, the type of process used, and the presence of some additives. When the nuts begin to germinate, when they are not ripe, or when the drying has been poorly done, the butter obtained tends to turn to a green or yellow-green color, according to the proportion of nuts sprouted. Seventy-seven percent of the women processors report producing good butter of a white-gray color. A yellow butter color is not, however, related to the quality of the nuts used in its processing, but the result of the addition of powdered bark or root from different plants, e.g., the root of Cochlospermum tinctorium, which is added to the shea oil before its solidification. These additives were used by the women to change the color of their butter to satisfy their customers.

Consumers buying shea butter for household consumption searched for characteristics based on extrinsic features such as color, taste, smell, and texture. Indeed, $66 \%$ of consumers preferred a greyish-white color, while $28 \%$ chose a yellow color. The Boo ethnic group preferred white or gray-white shea butter, while the Fulani and Gando preferred butter with a yellow or white-yellow 
color. Indeed, Fulani and Gando processors used additives during processing to give it a yellow coloring. The Baatombu did not show any pattern of preferences for butter color. Moreover, almost all consumers (96\%) were looking for butter with a slightly floral odor, fruity taste, and solid texture (100\%).

\subsection{Selection of Variables and Contingent Valuation}

The key variables that could explain the willingness to pay/accept for the new hypothetical products are summarized in Table 3. These characteristic variables are considered to be eventual explanatory variables in the empirical model.

Table 3. Description of the variables.

\begin{tabular}{cl}
\hline Variable & \\
\hline KALALE & Kalalé village $=1 ;$ others $=0$ \\
FULANI & Fulani ethnic group $=1 ;$ others $=0$ \\
PASTOR & Pastoralist men Yes $=1 ;$ No $=0$ \\
ADULT & Active adults in the household (men and women, more than 15 years old) Yes $=1 ;$ Others $=0$ \\
AMAN & Active men in the household (more than 15 years old) Yes $=1 ;$ No $=0$ \\
EDU1 & No education Yes $=1 ;$ No $=0$ \\
EDU4 & High education Yes $=1 ;$ No $=0$ \\
COLOR & Preference for grey-brown color nuts Yes $=1 ;$ No $=0$ \\
LONG & Preference for long nuts Yes $=1 ;$ No $=0$ \\
WEIGHT & Preference for heavy nuts Yes $=1 ;$ No $=0$ \\
DIAMET & Preference for large diameter nuts Yes $=1 ;$ No $=0$ \\
BUTCOL & Butter color to be considered in the premium Yes $=1 ;$ No $=0$ \\
ODOR & Butter odor to be considered in the premium Yes $=1 ;$ No $=0$ \\
FLAVOR & Butter flavor to be considered in the premium Yes $=1 ;$ No $=0$ \\
BUTTEX & Butter texture to be considered in the premium Yes $=1 ;$ No $=0$ \\
\hline
\end{tabular}

Almost all participants were willing to contribute to ensure the quality of both nuts for processing and butter for household consumption. The models explain the factors proposed in the study that can affect this decision by $15-42 \%$ (Table 4 ).

All processors were willing to pay a maximum average premium of XOF 734 for nuts of a certain quality. The most important attributes influencing processors' choice were color, length, and weight. The premium processors were willing to pay for the quality of nuts is reduced when the nuts do not meet the desired quality: by XOF 358 for the length, by XOF 390.67 for the weight, and by XOF 153.85 for the color.

All of the interviewed consumers were willing to pay an average premium of $49.97 \mathrm{XOF}$ (149.97 XOF) for butter with the desired quality and characteristics. The model explains in a $42 \%$ the factors that affect this decision, with a constant 68.59 XOF. The most important attributes of butter for the consumer were color and smell. If there is a variation in relation to their preferences, this premium will be reduced (24.02 XOF for color and 31.77 XOF for odor). Referring to the level of education, the premium will be reduced by $13.23 \mathrm{XOF}$ if the respondent did not follow a regulated education, and, with the higher level, it will increase by 101.80 XOF. If they are from Kalalé, the WTP will be increased by 18.96 XOF; if they are Fulani, it will be increased by 16.92 XOF; and if they are men pastoralists, it will increase by $50.68 \mathrm{XOF}$. The women processors (96\%) were willing to accept an average of 153.45 XOF (253.455 XOF in total) for a butter that they consider to be of better quality, i.e., with the characteristics they considered to produce a good-quality butter.

The fitness of the model is nearly $15 \%$, and they would accept a minimum of 27.92 XOF. The most important attributes were color, smell, and texture. This premium would be increased for color (23.52 XOF) and smell (23.35 XOF), but decreased for texture (20.29 XOF). 
Table 4. Ordinary least squares model.

\begin{tabular}{|c|c|c|c|c|c|c|c|c|c|}
\hline \multicolumn{2}{|c|}{ Butter WTP Consumers } & \multirow[t]{2}{*}{ (1) } & \multicolumn{7}{|c|}{ Butter WTA Processors (1) } \\
\hline Variable & Coefficient & & SE & t-Ratio & Variable & Coefficient & & SE & t-Ratio \\
\hline Constant & 68.588 & $* * *$ & 15.544 & 4.41 & Constant & 27.937 & $* *$ & 16.065 & 9.84 \\
\hline BUTCOL & -24.016 & $* * *$ & 6.870 & -3.50 & BUTCOL & 23.524 & $* * *$ & 12.178 & -3.45 \\
\hline ODOR & -31.771 & $* * *$ & 9.352 & -3.40 & ODOR & 23.351 & $*$ & 17.080 & 4.04 \\
\hline FLAVOR & 16.987 & & 10.443 & 1.63 & FLAVOR & 0.048 & & 16.880 & -3.87 \\
\hline TEXTURE & 2.782 & & 12.192 & 0.23 & BUTTEXT & -20.292 & * & 14.859 & -4.54 \\
\hline KALALE & 18.959 & $* * *$ & 4.893 & 3.87 & KALALE & 1.257 & & 8.209 & -0.47 \\
\hline FULANI & 16.928 & $* *$ & 7.647 & 2.21 & FULANI & 10.600 & & 10.155 & 2.69 \\
\hline EDU1 & -13.229 & $* *$ & 6.512 & -2.03 & & & & & \\
\hline EDU4 & 101.802 & $* * *$ & 18.928 & 5.38 & & & & & \\
\hline PASTOR & 50.680 & $* * *$ & 17.565 & 2.89 & & & & & \\
\hline AMAN & -9.814 & $*$ & 5.029 & -1.95 & & & & & \\
\hline ADULT & 8.664 & & 11.511 & 0.75 & & & & & \\
\hline \multicolumn{5}{|c|}{$R^{2}$ (adjusted) $=42.21 \%$} & \multicolumn{5}{|c|}{$R^{2}$ (adjusted) $=14.97 \%$} \\
\hline$n=184$ & & & & & $n=123$ & & & & \\
\hline Average WTP & 49.97 & & & & Average WTP & 53.45 & & & \\
\hline \multicolumn{5}{|c|}{ Nut WTP Processors (2) } & & & & & \\
\hline Variable & Coefficient & & SE & t-Ratio & & & & & \\
\hline Constant & 1055.810 & $* * *$ & 87.687 & 12.04 & & & & & \\
\hline COLOR & 153.850 & $*$ & 78.574 & 1.96 & & & & & \\
\hline LONG & -358.045 & $* * *$ & 81.682 & -4.38 & & & & & \\
\hline WEIGHT & -390.666 & $* * *$ & 74.045 & -5.28 & & & & & \\
\hline DIAMET & -24.371 & & 79.722 & -0.31 & & & & & \\
\hline KALALE & -230.535 & $* * *$ & 83.576 & -2.76 & & & & & \\
\hline FULANI & 300.250 & $* * *$ & 104.231 & 2.88 & & & & & \\
\hline \multicolumn{5}{|c|}{$R^{2}($ adjusted $)=35.32 \%$} & & & & & \\
\hline \multicolumn{10}{|l|}{$n=123$} \\
\hline Average WTP & 734.55 & & & & & & & & \\
\hline \multicolumn{10}{|c|}{$\begin{array}{l}\text { (1) Referred to } 125 \text { grs of butter } \\
\text { (2) Referred to } 25 \mathrm{kgs} \text { of nuts }\end{array}$} \\
\hline$* * * * *, *=$ & Signimicanc & $\pi$ & $0,10 \%$ & & & & & & \\
\hline
\end{tabular}

\section{Discussion}

This study assessed the factors that affect the shea butter chain and recommends strategies to improve quality in order to achieve higher household revenues. Some important social keys were also identified for consideration in the conservation and sustainable management planning of shea tree resources. Even if the data were collected between November 2004 and February 2005, some main reasons maintain the research questions and the current results: Traditional organization and the shea butter chain have slightly evolved during the last years in the area [23]; the need to improve the quality of shea butter production for the market is still a challenge [13], as well as the pending development of price premiums for the supply of improved products. This would bring the opportunity for rural producers to form tight links with buyers, institutions, or associations [3].

The income from shea products does not match Beninese local producers' expectations. Butter-making in the traditional way is a very painstaking process, involving multiple steps that can significantly affect the quality of the butter. There are particular constraints identified by women processors in the marketing of the shea butter: low production capacity, flow, butter conservation, and lack of market opportunities. Despite the efforts to promote the market for shea butter, researchers have argued that the absence of standardized measures (size, color, and weight) and the lack of market opportunities remain the main problems facing shea processors [9]. Even if the transformation and trade of quality butter is profitable, with positive gross margins average values, and net incomes and net returns on investments at the local level [31], the use of the traditional process results too often in 
poor-quality butter. In Ghana, women processors stated that they would be able to produce high-quality butter if they had the necessary equipment, and therefore would get competitive prices [13].

Additional means could help in improving the quality, as in the control and certification of shea products [32], although certification is costly and requires consumers to bear part of the cost. Interestingly, our study shows that the additional cost to ensure the quality of the shea butter would be covered by a premium to be paid by the consumers. Shea butter processors and consumers interviewed are, respectively, willing to accept (WTA, 28 XOF) and to pay (WTP, 69 XOF) over 100 XOF to guarantee the production and marketing of shea butter based on quality characteristics. In addition, $96 \%$ of the processors are willing to pay double (1056 XOF more over 1000 XOF) to ensure the supply of shea nuts for their processing into butter.

\subsection{Shea Product Preferences by Socioeconomic Characteristics}

Socioeconomic characteristics such as belonging to the Fulani ethnic group and being from Kalalé (the center of the district), significantly influence the willingness to pay of consumers of butter and nut processors. The level of education and being pastoralist also influence consumers' willingness to pay.

The preferred shea product characteristics are given more value by the Fulani ethnic group and pastoralist men. Fulani have been nomads or semi-nomadic pastoralists for centuries, but West African traditional specializations into agriculture and pastoral production systems are undergoing a process of change, affecting not only Fulani but other ethnic groups [33]. Where shea tree parklands are found, agriculturalist ethnic groups (Boo, Baatombu, and Gando, in our study) usually included shea butter for cooking the dishes. Fulani diet, in contrast, used butter from milk for cooking. Our results reflect these changes and the different behavior the Fulani show in comparison to the other ethnic groups: they show a higher WTP for both the purchase of shea butter (17 XOF) and nuts (300 XOF). To some extent, the butter from milk traditionally used in their dishes has been replaced by shea butter, while other ethnic groups have significantly reduced the food uses of shea, replacing it with other types of fat (i.e., locally produced palm or peanut oil, or other kinds of imported oil). Outside the Fulani, most women in Djougou (Benin) no longer use shea butter for cooking, replacing it with palm oil [6]. In a study in Burkina Faso, the Fulani were the group that most often used shea butter for cooking food and those that least commercialized it [34], and in Benin, Honfo [25] especially describes the Fulani as involved in the production and processing of shea butter, among others.

The fact that women are not the only shea actors in this group could be a reason why the Fulani and pastoralist men show a high WTP shea butter. Bidou et al. [6] found that, in Northern Benin, one-third of the Fulani women got help from their husbands with nut transportation. The participation of men in value chain activities traditionally reserved for women has been reported in other contexts when these activities become more remunerative [19], while the access to the land and to shea resources remains controlled by men [27]. Furthermore, in areas of high production of butter, the international marketing of the shea nuts and butter can be a source of gender conflict in the household [19]. When the value of the raw or processed shea products increases, the rights to access and the control of resources can be renegotiated and amended by the holder of the rights and other users [27]. Therefore, the future of the shea parklands and the development of shea butter market chains depends, to a large extent, on the evolution of gender relationships, which are subject to rapid cultural changes [6]. This has been the case in Ghana [15], where, in half of the households, the husband is involved in the decision-making process because of the significant income generated by the nuts. To increase women's profitability from the shea butter local market, a process supporting women in the transformation, negotiation, quality, and quantity of the production is needed [31].

\subsection{Nut and Butter Characteristics for the Certification and Labeling of Shea Products}

The color, length and weight of the nuts, as well as the color, smell and the texture of the butter are the factors that significantly influence the willingness to pay for a specific quality butter or nuts and to accept for the quality of the butter. 
Consumers and processors agree on the most important characteristics of the butter. The variation in shea nut color would increase the premium to be paid by $154 \mathrm{XOF}$; this could be referring to the conservation status of dried nuts for storage or for being processed into butter. In addition, the size and weight of the nuts have an effect on butter performance: WTP decreases by 358 XOF for the length and 391 XOF for the weight. These results are in line with those found in a broader area of Benin, showing the degree of drying of the nuts and their appearance as the most important characteristics for the processors, and the color of the butter for the consumers [25]. Color and smell refer to the quality of the butter, which has been produced with nuts in good conditions, and the preservation of the butter itself. The preferred color varies from white to yellowish. Fulani and Gando respondents like a yellow color-resulting from adding natural products-better. A green color, together with an acid odor, mean that a high percentage of sprouted nuts have been used. The acid smell may also indicate that the butter is not from the current year's campaign and that it has not been well preserved. The processors' WTA decreases by 20 XOF for improving the texture of shea butter, which is probably either due to the current technology applied, or because they already estimate they produce high-quality butter. Furthermore, Bernard and Charlotte [35] found that the perception about the density of the product depends on the destination: light for sale by volume, heavy for sale by weight, and the price of butter paid by buyer intermediaries.

The local shea butter labeling and certification is supported by other valuation studies based on different agricultural and nontimber forest products. These studies have shown consumers' willingness to pay for certified and labeled safety or for improved products, as well as for assuring the availability of products on the market. Both young, well-educated, and wealthy consumers of certified vegetables [36], and the majority of the consumers of meat products [37], would pay price premiums to avoid health-related risks in Ghana. Consumers in Kenia place high value on the safety of leafy vegetables, suggesting the existence of a great potential for domestic market actors to improve leafy-vegetable value chains [38], as well as that of maize tested as aflatoxin-free and labeled [39] and porridge flour with improved nutritional aspects [40]. In Niger, the leaves of Adansonia digitata L. (African baobab) are highly important culturally as healthy ingredients in Nigerien traditional dishes. As the resource is declining, the majority of local consumers are willing to contribute to a baobab conservation program in order to ensure its availability in the market [41]. Our study offers new insights for the development of quality standards and certifications, as well as for shea tree resources sustainable management and conservation that consider ethnic and gender issues.

\subsection{Consequences on Shea Tree Resources Management and Conservation}

The knowledge that women have about the special features of the nuts producing butter of high quality represents a chance to ensure and to improve the supply of shea nuts. In Benin, shea tree is considered an endangered species, which is probably a consequence of the lack of appropriate protection strategies and effective regeneration methods [6], besides land management practices such as lack of fallow [42]. A great potential within the species has been found in the variation of important fruit and nut characters and yield, with a significant effect due to land use (agroforestry parklands versus protected areas) and interannual variation [43-46]. The results from the surveys in our study revealed that the nuts are picked and/or purchased without a clear grading technique, but that women could identify the factors that affect the quality and maturity of the nuts.

The women's knowledge about shea resources variation needs to be considered when planning sustainability and conservation strategies. However, they do not own the property rights of land or trees, nor can their opinions decisively influence their preservation, protection, or regeneration. In contrast, men usually do so, and they are the ones who are able to grant access to the natural resources [47]. Furthermore, landowners can have other interests, such as planting cashew orchards or cutting the shea trees to obtain wood. Merely including women in the shea nut production would not guarantee their empowerment, or the success on income development initiatives. Therefore, more equitable gender relationships should also be driven [19]. 


\section{Conclusions}

This study showed that the price to ensure the quality standards of the shea butter would be covered by a premium to be paid by the consumers. The color, smell, and texture of the butter on the one hand, and the color, length, and weight of the nuts, on the other hand, significantly influence consumers' willingness to pay. The development of the shea value chain should include the key actors in the production, collection, and processing of the shea nuts, such as the Fulani ethnic group, pastoralist men, and the women who process the nuts.

All the interviewed shea butter processors and consumers aimed at guaranteeing the quality of the shea butter production, and there was an agreement on the most important characteristics of the butter. Our study shows that a price that ensured the quality of the shea butter would be covered by a premium to be paid for by the consumers. The price premium could help to reduce the constraints that women processors find in relation to the processing and marketing of the shea butter which, in turn, are related to the traditional processing method, including production capacity, product conservation, flow, and lack of market opportunities.

This study offered key elements to increase Benin's shea products' value and the development of their potential, through the increased availability of good-quality products, and to consider labeling and certification of local shea butter. The color, smell, and texture of the butter, as well as the color, length, and weight of the nuts, significantly influence the willingness to pay for a specific quality of butter or nuts. These preferences may be considered in the design of a quality label for shea products. Other elements, such as the factors influencing the nutrition characteristics and safety, the volume or weight, and the packaging of the final product, should be considered in further studies, as the model is not completely explicative of the factors that influence the willingness to participate in the improvement of shea production quality.

New insights into shea tree sustainable management and resource conservation that consider ethnic and gender factors are offered, and the development of shea butter quality standards and certification are proposed. As the development of local shea butter production and marketing has a direct consequence on the management and conservation of the tree resources, both the Fulani ethnic group and pastoralist men should be included in the development of management programs, as well as a gender perspectives that aim at avoiding women having their profits in the shea butter local market reduced.

Moreover, the knowledge women have about shea resource variation should be considered when planning sustainable production and conservation strategies. The different existing social initiatives for shea production should invest more in capacity building, improvement of the local processing and dissemination, and developing institutional strategies.

As previously stated, the results are preliminary. This study was conceived at a period of great interest in boosting the shea product market, but the models explain $15-42 \%$ of the factors that can affect the WTP/WTA decision. Nowadays, other methodological approaches, such as auctions or choice experiments, can be considered as a superior alternative to analyze the preferences for marketed goods. Moreover, further investigations are needed on the preferences of shea butter production and their links to the conservation and sustainable management planning of shea tree resources.

Supplementary Materials: The following are available online at http://www.mdpi.com/1999-4907/11/1/13/s1.

Author Contributions: T.N., O.C., and and D.A. jointly conceived of and designed the study; T.N. implemented the study and performed the preliminary analyses; M.S. performed the formal analysis and contingent valuation modelling approach; R.A. was the supervisor of the INIA-Bioversity International Joint collaboration; D.A. wrote the first draft of this article, to which the rest of the other authors provided their input. All authors have read and agreed to the published version of the manuscript.

Funding: This research was performed within the framework of the (i) "Variation of a Sub-Saharan agroforestry species. Shea butter tree (Vitellaria paradoxa) selection; morphological and phenological (leafing, flowering and fruiting) variation in Kalalé district (Northern Benin)" and was co-funded by AECID (International Cooperation and Development Spanish Agency), the (ii) Strengthening Regional Collaboration in Conservation and Sustainable Use of Forest Genetic Resources in Latin America and Sub-Saharan Africa. INIA-Bioversity International Joint 
collaboration in the SAFORGEN Programme Project financed by INIA, and the (iii) the Project AEG 17-048 established in the frame of the measure 15.2 "support to the conservation and use of forest genetic resources" and under Regulation (EU) No. 1305/2013 of the European Parliament and of the Council of 17 December 2013, on support for rural development by the European Agricultural Fund for Rural Development (EAFRD), with $75 \%$ co-financing.

Acknowledgments: We would like to thank all the people who participated in this study, mainly the respondents and the countless people who cooperated selflessly in the field work, including the local translators. We give our thanks to Oscar Eyog-Matig, former coordinator of SAFORGEN (Sub-Saharan African Forest Genetic Resources program), for his continued support in conducting this study. The authors wish to thank Patricia Grant for her editorial contribution.

Conflicts of Interest: The authors declare no conflicts of interest.

\section{References}

1. Naughton, C.C. Household food security, economic empowerment, and the social capital of women's shea butter production in Mali. Food Secur. 2017, 773-784. [CrossRef]

2. Nde, B.D.; Mohammed, M.A.; César, K.; Zéphirin, M. Production zones and systems, markets, benefits and constraints of shea (Vitellaria paradoxa Gaertn) butter processing. Oilseeds Fats Crop. Lipids 2014, 21. [CrossRef]

3. Lovett, P.N. The Shea Butter Value Chain: Production, Transformation and Marketing in West Africa; West Africa Trade Hub (WATH) Technical Report; USAID: Washington, DC, USA, 2004; pp. 1-40.

4. Kafilatou, S.T.; Léonard, A.E.; Vincent, E.; Eliassou, S.H. Agro-morphological variability of shea populations (Vitellaria paradoxa CF Gaertn) in the Township of Bassila, Benin Republic. J. Plant Breed. Crop Sci. 2015, 7, 227-236. [CrossRef]

5. Akpona, T.J.D.; Akpona, H.A.; Djossa, B.A.; Savi, M.K.; Daïnou, K.; Ayihouenou, B.; Kakaï, R.G. Impact of land use practices on traits and production of shea butter tree (Vitellaria paradoxa C. F. Gaertn.) in Pendjari Biosphere Reserve in Benin. Agrofor. Syst. 2016, 607-615. [CrossRef]

6. Bidou, J.-É.; KouKPéré, A.; Droy, I. Agroforesterie et Services Écosystémiques en Zone Tropicale; Éditions Quæ: Versailles Cedex, France, 2019; ISBN 9782759230594.

7. Seghieri, J. Shea tree (Vitellaria paradoxa Gaertn. f.): From local constraints to multi-scale improvement of economic, agronomic and environmental performance in an endemic Sudanian multipurpose agroforestry species. Agrofor. Syst. 2019, 1. [CrossRef]

8. Reynolds, N. Investing in Shea in West Africa: A US Investor's Perspective; West Africa Trade Hub (WATH) Technical Report; USAID: Washington, DC, USA, 2010; pp. 1-23.

9. Al-hassan, S. Market Access Capacity of Women Shea Processors in Ghana. Eur. J. Bus. Manag. 2012, 4, 7-18.

10. Pouliot, M. Contribution of "Women's Gold" to West African Livelihoods: The Case of Shea (Vitellaria paradoxa) in Burkina Faso. Econ. Bot. 2012, 66, 237-248. [CrossRef]

11. Pouliot, M.; Elias, M. Geoforum To process or not to process? Factors enabling and constraining shea butter production and income in Burkina Faso. Geoforum 2013, 50, 211-220. [CrossRef]

12. Bello-bravo, J.; Lovett, P.N.; Pittendrigh, B.R. The Evolution of Shea Butter's "Paradox of paradoxa" and the Potential Opportunity for Information and Communication Technology (ICT) to Improve Quality, Market Access and Women's Livelihoods across Rural Africa. Sustainability 2015, 7, 5752-5772. [CrossRef]

13. Kombiok, E.; Agbenyega, O. The characteristics of financing arrangements for the production and marketing of shea (Vitellaria paradoxa) butter in Tamale in the Northern Region of Ghana. South. For. J. For. Sci. 2017, 1-8. [CrossRef]

14. Awo, M.A. A Survey-Based Qualitative Analysis of the Institutional Structures and Policy Measures in the Shea Sector of Ghana. Res. World Econ. 2018, 9, 24-37. [CrossRef]

15. Kent, R. "Helping" or "Appropriating"? Gender Relations in Shea Nut Production in Northern Ghana. Soc. Nat. Resour. 2018, 31, 367-381. [CrossRef]

16. Hammond, J.; Van Wijk, M.; Pagella, T.; Carpena, P.; Skirrow, T.; Dauncey, V. The Climate-Smart Agriculture Papers; Springer: Cham, Switzerland, 2019; pp. 215-226. ISBN 9783319927985. [CrossRef]

17. Rousseau, K.; Gautier, D.; Wardell, D.A. Coping with the Upheavals of Globalization in the Shea Value Chain: The Maintenance and Relevance of Upstream Shea Nut Supply Chain Organization in Western Burkina Faso. World Dev. 2015, 66, 413-427. [CrossRef] 
18. Kodua, T.T.; Ankamah, J.; Addae, M. Assessing the profitability of small scale local shea butter processing: Empirical evidence from Kaleo in the Upper West region of Ghana. Cogent Food Agric. 2018, 13, 1-11. [CrossRef]

19. Elias, M.; Arora-jonsson, S. Negotiating across difference: Gendered exclusions and cooperation in the shea value chain. Environ. Plan. D Soc. Space 2016, 35, 1-19. [CrossRef]

20. Rousseau, K.; Gautier, D.; Wardell, D.A. Socio-economic differentiation and shea globalization in western Burkina Faso: Integrating gender politics and agrarian change. J. Peasant Stud. 2017, 46, 1-20. [CrossRef]

21. Kabiru, S.M. Utilisation of Modern Processing Technologies among Shea Butter Processors in Niger State, Nigeria. J. Agric. Ext. 2017, 27-38. [CrossRef]

22. Ministère d'État chargé du Plan et du Développement. République du Bénin. In Plan National de Développement 2018-2025; BéninRévélé: Portonovo, Bénin, 2018.

23. Ahouansou, R.H.; Agbobatinkpo, P.B.; Sanya, A.; Gnonlonfin, B.; Fandohan, P. Comparative study of some physical properties of the shea kernels in the shea parks in Benin. Int. J. Biol. Chem. Sci. 2016, 10, 2151-2162. [CrossRef]

24. Association Karité Bénin. Compte Rendu de la Conférence Annuelle du Karité; CAK: Natitingou, Bénin, 2015.

25. Honfo, F.G. Indigenous Knowledge of Shea Processing and Quality Perception of Shea Products in Benin. Ecol. Food Nutr. 2012, 37-41. [CrossRef]

26. Gnanglè, P.C.; Yabi, J.; Glèlè, K.R.; Sokpon, N. Changements climatiques: Perceptions et stratégies d'adaptations des paysans face à la gestion des parcs à karité au Centre-Bénin. In Proceedings of the SIFEComm, Niamey, Niger, 2005.

27. Agúndez, D.; Houtondji, F.; Simeni-Tchuinte, G. Land tenure, access and gender considerations in the Management and conservation of agroforestry resources in the North of Benin Republic. In Agrarian Research for Sustainable Development: International Study Cases; AcademicPres Publishing: Cluj-Napoca, Romania, 2014; pp. 181-202. ISBN 978-973-744-364-9.

28. Mitchell, R.C.; Carson, R.T. Using Surveys to Value Public Goods: The Contingent Valuation Method; Resources for the Future Press: Washington, DC, USA, 1989.

29. Carson, R.T.; Flores, N.E.; Meade, N.F. Contingent valuation: Controversies and evidence. Environ. Resour. Econ. 2001, 19, 173-210. [CrossRef]

30. Crastes dit Sourd, R.; Zawojska, E.; Mahieu, P.-A.; Louviere, J. Mitigating strategic misrepresentation of values in open-ended stated preference surveys by using negative reinforcement. J. Choice Model. 2018, 28, 153-166. [CrossRef]

31. Niculescu, N.; Badini, Z.; Diarra, M. Le beurre de karité au Burkina Faso: Entre marché domestique et filières d'exportation. Cah. Agric. 2009, 18, 369-375.

32. Garba, I.D.; Sanni, S.A.; Adebayo, C.O. Analyzing the Structure and Performance of Shea Butter Market in Bosso and Borgu Local Government Areas of Niger State, Nigeria. Int. J. u-e-Serv. Sci. Technol. 2015, 8, 321-336. [CrossRef]

33. Petit, S. Parklands with fodder trees: A Fulße response to environmental and social changes. Appl. Geogr. 2003, 23, 205-225. [CrossRef]

34. Tiétiambou, F.R.S.; Lykke, A.M.; Korbéogo, G.; Thiombiano, A.; Ouédraogo, A. Perceptions et savoirs locaux sur les espèces oléagineuses locales dans le Kénédougou, Burkina Faso. Bois Forets des Trop 2016, 327, 39-50. [CrossRef]

35. Bernard, P.B.; Charlotte, K. Des savoir-faire locaux entre IG et standardisation des produits: Exemple du beurre de karité au Burkina Faso. In Proceedings of the Actes du Colloque Localisation et Circulation des Savoir-Faire en Afrique, Aix-en-Provence, France, 19-20 March 2008; pp. 1-20.

36. Amfo, B.; Donkoh, S.A.; Gershon, I.; Ansah, K. Determinants of consumer willingness to pay for certified safe vegetables. Int. J. Veg. Sci. 2018, 25, 1-13. [CrossRef]

37. Owusu-sekyere, E.; Owusu, V.; Jordaan, H. Consumer preferences and willingness to pay for beef food safety assurance labels in the Kumasi Metropolis and Sunyani Municipality of Ghana. Food Control. 2014, 46, 152-159. [CrossRef]

38. Ngigi, M.W.; Okello, J.J.; Lagerkvist, C.J.; Karanja, N. Assessment of developing-country urban consumers'willingness to pay for quality of leafy vegetables: The case of middle and high income consumers in Urban Consumers' Willingness to Pay for Quality of Leafy Vegetables along the Value Chain: The Case o. Int. J. Bus. Soc. Sci. 2011, 2, 208-216. 
39. De Groote, H.; Narrod, C.; Kimenju, S.C.; Bett, C.; Scott, R.P.B.; Tiongco, M.M.; Gitonga, Z.M. Measuring rural consumers'willingness to pay for quality labels using experimental auctions: The case of aflatoxin-free maize in Kenya. Agric. Econ. 2016, 47, 33-45. [CrossRef]

40. Chege, C.G.K.; Sibiko, K.W.; Wanyama, R.; Jager, M.; Birachi, E. Are consumers at the base of the pyramid willing to pay for nutritious foods? Food Policy 2019, 87, 101745. [CrossRef]

41. Agúndez, D.; Lawali, S.; Alía, R.; Soliño, M. Consumer Preferences for Baobab Products and Implication for Conservation and Improvement Policies of Forest Food Resources in Niger (West Africa). Econ. Bot. 2018, 72, 396-410. [CrossRef]

42. Aleza, K.; Villamor, G.B.; Nyarko, B.K.; Wala, K.; Akpagana, K. Shea (Vitellaria paradoxa Gaertn C. F.) fruit yield assessment and management by farm households in the Atacora district of Benin. PLoS ONE 2018, 13, e0190234. [CrossRef] [PubMed]

43. Bondé, L.; Ouédraogo, O.; Ouédraogo, I.; Thiombiano, A.; Boussim, J.I. Variability and estimating in fruiting of shea tree (Vitellaria paradoxa C. F. Gaertn) associated to climatic conditions in West Africa: Implications for sustainable management and development. Plant. Prod. Sci. 2018, 22, 143-158. [CrossRef]

44. Bondé, L.; Ouédraogo, O.; Traoré, S.; Thiombiano, A.; Boussim, J.I. Impact of environmental conditions on fruit production patterns of shea tree (Vitellaria paradoxa C. F. Gaertn) in West Africa. Afr. J. Ecol. 2019, 57, 353-362. [CrossRef]

45. Ouedraogo, S.; Bonde, L.; Ouedraogo, O.; Thiombiano, A.; Boussim, I.J.; Ouedraogo, S.; Bonde, L.; Ouedraogo, O.; Ouedraogo, A. To What Extent Do Tree Size, Climate and Land Use Influence the Fruit Production of Balanites aegyptiaca (L) Delile in Tropical Areas (Burkina Faso)? To What Extent Do Tree Size, Climate and Land Use Influence the Fruit Production of Balanites aegyp. Int. J. Fruit Sci. 2019, 1-18. [CrossRef]

46. Gwali, S.; Bosco, J.; Okullo, L.; Eilu, G.; Nakabonge, G.; Nyeko, P.; Vuzi, P. Traditional management and conservation of shea trees (Vitellaria paradoxa subspecies nilotica) in Uganda. Environ. Dev. Sustain. 2012, 347-363. [CrossRef]

47. Rousseau, K.; Gautier, D.; Wardell, D.A. Renegotiating Access to Shea Trees in Burkina Faso: Challenging Power Relationships Associated with Demographic Shifts and Globalized Trade. J. Agrar. Chang. 2016. [CrossRef] 